\title{
A Case of Pleomorphic Adenoma of the Nasal Ala
}

\author{
Soo Young Choi ${ }^{\mathbb{D}}$, Hee Jin Kang, Sung Wan Kim ${ }^{\mathbb{D}}$, and Jin-Young Min $\mathbb{C D}^{\mathrm{D}}$ \\ Department of Otorhinolaryngology-Head and Neck Surgery, School of Medicine, Kyung Hee University, Seoul, Korea
}

\section{비익에 발생한 다형성 선종 1예}

최수영 · 강희진 · 김성완 · 민진영

경희대학교 의과대학 이비인후과학교실

\author{
Received October 5, 2020 \\ Revised November 11, 2020 \\ Accepted November 19, 2020 \\ Address for correspondence \\ Jin-Young Min, MD, PhD \\ Department of Otorhinolaryngology- \\ Head and Neck Surgery, \\ School of Medicine, \\ Kyung Hee University, \\ 23 Kyungheedae-ro, \\ Dongdaemun-gu, \\ Seoul 02447, Korea \\ Tel $+82-2-958-8474$ \\ Fax $+82-2-958-8470$ \\ E-mail happyjy416@gmail.com
}

Pleomorphic adenoma occurs primarily in the major salivary glands, but very rarely in the nose. Treatment of nasal pleomorphic adenoma, like pleomorphic adenoma of the major salivary gland, is also a complete resection. Since most are confined to the nasal cavity and do not invade cartilage or other tissues, it can be removed relatively simply by nasal endoscopic surgery. We report a case where a pleomorphic adenoma arising from the right nasal ala invades the lateral crus of lower lateral cartilage, where a part of the cartilage was excised along with removal of the tumor and reconstructed with nasal septal cartilage. Eight months after surgery, the external deformity of nose was not observed and there was no recurrence.

Korean J Otorhinolaryngol-Head Neck Surg 2021;64(10):751-4

Keywords Nose; Nose deformities acquired; Nose neoplasms; Pleomorphic adenoma.

\section{서 론}

다형성 선종(pleomorphic adenoma)은 타액선에서 기원하 는 양성종양으로 두경부 선조직 양성종양 중 가장 흔하다고 알려져 있고, 주로 이하선, 악하선 등의 대타액선에서 발생하 나 소타액선에서도 드물게 발생한다. 또한 구순, 연구개, 눈물 샘 등에서 발생했다는 보고들이 있으며 아주 드물게 비강, 부 비동에서 발생하기도 한다. ${ }^{1)}$ 남자보다 여자에게 호발하고 20 40 대에 가장 많이 발병한다.

한편, 비강이나 부비동에 존재하는 소타액선에서 발생하는 종양 중 약 $50 \%$ 는 악성이라고 보고되고 있으며, 가장 흔한 양성 종양은 다형성 선종이다. ${ }^{2)}$ 비 내 소타액선들은 주로 비 강 외측 벽에 존재하지만 다형성 선종은 주로 비중격에서 발 생하며 비측벽이나 비갑개에서 발생하는 경우는 드물다. ${ }^{3)}$ 비

This is an Open Access article distributed under the terms of the Creative Commons Attribution Non-Commercial License (https://creativecommons.org/licenses/by-nc/4.0) which permits unrestricted non-commercial use, distribution, and reproduction in any medium, provided the original work is properly cited.
외측에 다형성 선종이 생기는 경우는 극히 드문데 비주(nasal columella), 코위턱주름(nasomaxillary crease), 비전정(nasal vestibule) 등에서 발생했다는 보고들이 있다.-6) 최근 저자들 은 비익에 발생한 다형성 선종 1 예를 성공적으로 치료하였기 에 문헌 고찰과 함께 보고하는 바이다.

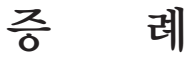

27세 남자 환자로 3개월 전부터 우측 비강 내에 보이는 종 물을 주소로 내원하였다. 처음 종물을 발견하고 크기가 작아 지켜보다가 점점 크기가 커져 내원하였으며, 이로 인해 우측 코막힘을 호소하였고 내원 2주 전, 3주 전 한 차례씩 코피가 났다고 하였다. 그 외 통증이나 소양감 등 다른 증상 호소는 없었으며 과거력과 가족력상 특이 사항은 없었다. 종물은 우 측 전비공을 거의 막고 있었으며 우측 비익 외측으로 돌출되 어 있었다(Fig. 1). 비내시경 검사상 우측 비익에 비강 내로 돌출되어 있는 장경 약 $1.5 \mathrm{~cm}$ 의 종물이 관찰되었고, 이학적 
검사상 단단하게 촉지되었고 압통 등은 없었다. 좌측 비강은 정상이었고 경부 림프절 비대나 다른 이비인후과적 이학적 검사상 특이점은 없었다. 혈액검사, 뇨검사, 신기능검사, 간기 능검사, 심전도검사 등도 정상이었다. 부비동 전산화단층촬영 에서 우측 비익에서 기원한 것으로 보이는 $1.4 \times 1.3 \mathrm{~cm}$ 크기 의 둥근 모양 종괴가 관찰되었다. 이 종괴는 주변 조직과 경 계가 명확하였고, 연부조직 음영을 보이고 비균일하게 조영증 강 되었다(Fig. 2).

2019년 12월 26일 전신마취하에 내시경하 종괴 제거술을 시행하였다. 우측 비익 내측면에 경계절개(marginal incision) 를 가하고 피하조직을 박리하고 피막이 손상되지 않도록 조 심스럽게 종괴를 제거하였다(Fig. 3). 종괴는 우측 하외측연 골(lower lateral cartilage)의 외측각(lateral crus)에 유착되 어 있었으며, 연골의 일부가 종괴로 인하여 압박되어 변형된 소견이 있었고, 박리가 어려워 일부를 같이 절제하고 결손이 생긴 부위는 비중격 연골의 일부를 채취하여 재건해주었다. 비중격 연골의 채취를 위해서 우측 점막에 Modified Killian 절개를 시행한 후 Freer 거상기로 비중격 연골의 연골막(perichondrium)을 조심스럽게 박리한 후 약 $1.0 \times 0.5 \mathrm{~cm}$ 크기로 비중격 연골을 채취하였다. 우측 하외측연골의 외측각의 결 손 부위에 맞게 채취한 비중격 연골을 다듬어 결손 부위에 위치시킨 후 5-0 PDS(Ethicon Inc., Somerville, NJ, USA) 를 이용하여 남아있는 우측 하외측연골에 고정하여 주었다. 경계절개한 부위와 비중격 연골을 채취한 부위는 5-0 Vicryl (Ethicon Inc.)로 단순 봉합해주었다.
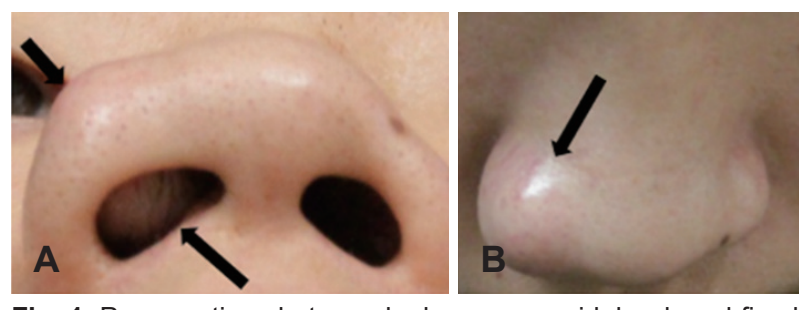

Fig. 1. Preoperative photograph shows an ovoid, hard, and fixed mass at the right nasal ala. Basal view (arrows) (A). Frontal view (arrow) (B).

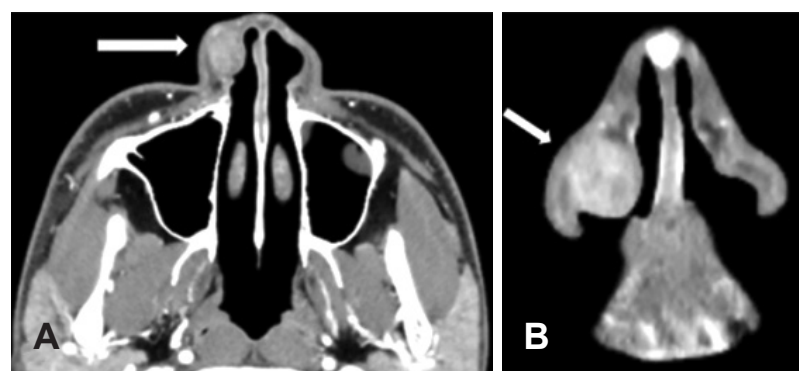

Fig. 2. Axial $(A)$ and coronal $(B)$ view of paranasal sinus CT with contrast show the well-defined, soft tissue density mass (arrow) with heterogenous enhancement at right nasal ala.
절제된 종괴는 육안상 약 $2.0 \times 1.0 \times 1.0 \mathrm{~cm}$ 크기로 주위 조 직과 비교적 경계가 명확하였고, 하외측연골의 일부를 침범 하는 것 이외에는 주변 조직과 유착되어 있지 않았다(Fig. 4). 육안 소견상 악성이 의심되지는 않았으며, 수술 중 시행한 동 결절편생검 결과에서 다형성 선종이 확인되었다. 병리조직학 적 소견상 절제된 조직은 $2.5 \times 2.0 \times 0.7 \mathrm{~cm}$ 크기의 난원형으 로 흰색의 섬유 조직으로 관찰되었고, 기질 내에서 선상 구조 를 보이는 상피성 세포들의 증식이 보이며 간엽성 및 상피성 성분의 이원적 구성을 보였다. 핵의 이형성 등 악성을 시사할 만한 소견은 없었다(Fig. 5).

환자는 수술 후 6일간 항생제, 진통소염제 등의 보존적 치 료를 시행하였고, 8 개월간 외래에서 추적 관찰하였고 재발의 소견 없으며, 외비 변형도 관찰되지 않는 좋은 상태를 유지하 고 있다(Fig. 6).

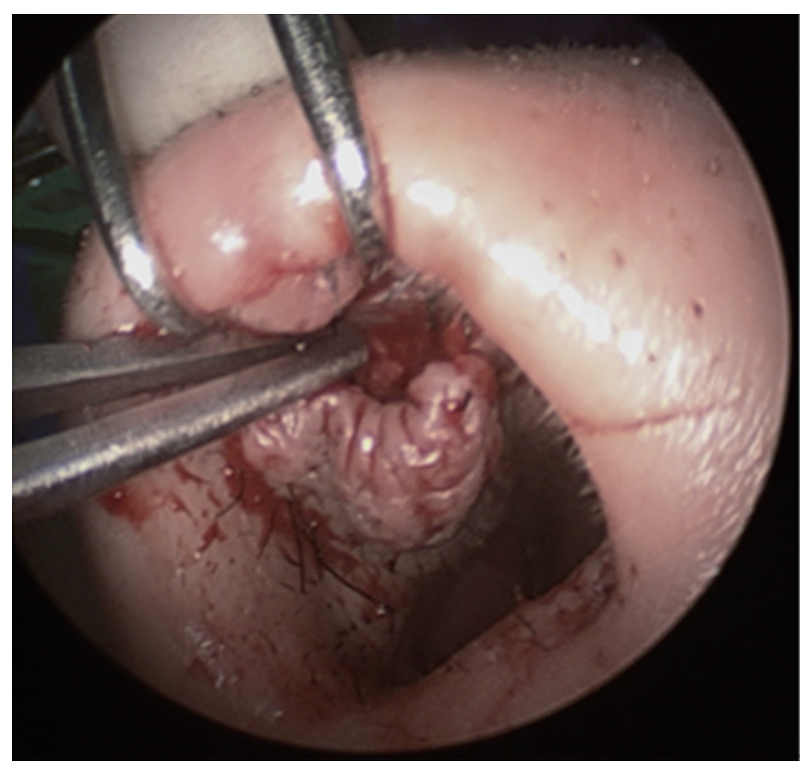

Fig. 3. The tumor was being removed from the right nasal ala.

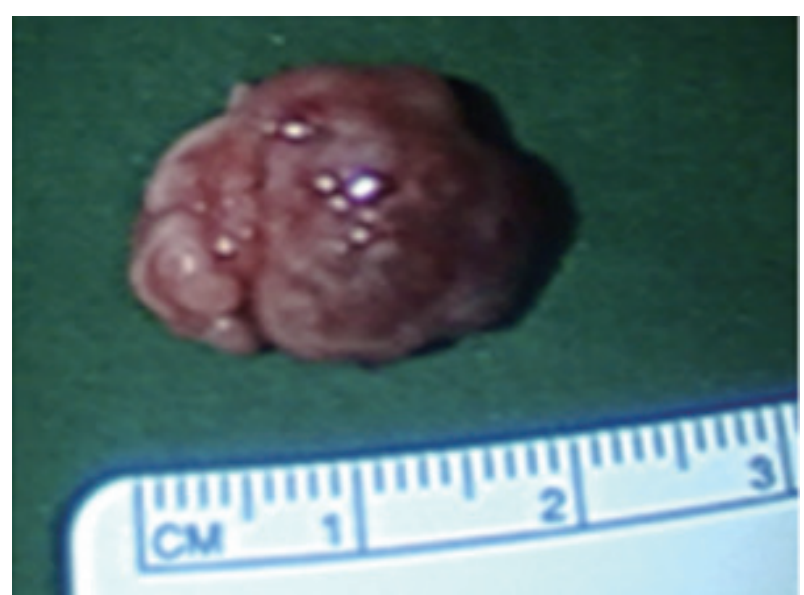

Fig. 4. The well-encapsulated tumor was whitish, $2.0 \times 1.0 \times 1.0$ $\mathrm{cm}$ sized. 


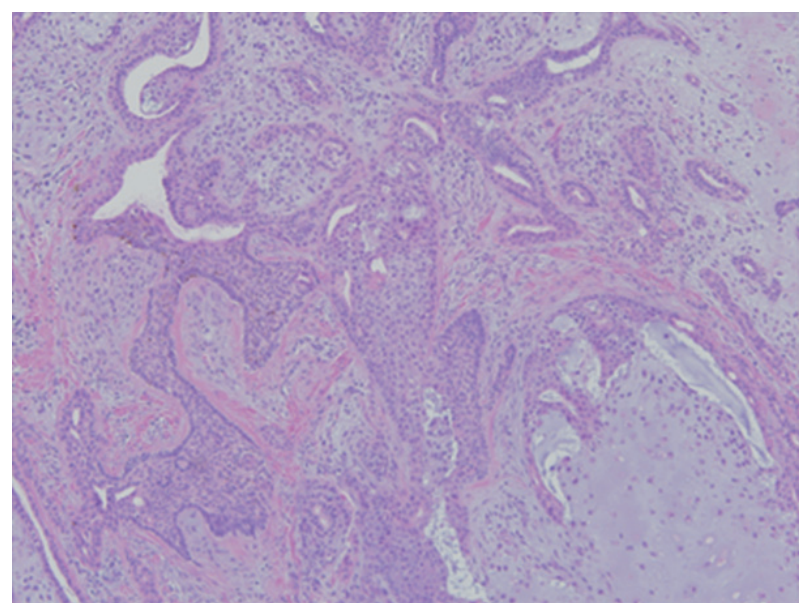

Fig. 5. Pathologic findings of the tumor show a myxochondroid stroma and abundant epithelial cells composed of tubuloductal structures (hematoxylin and eosin stain, $\times 100$ ).

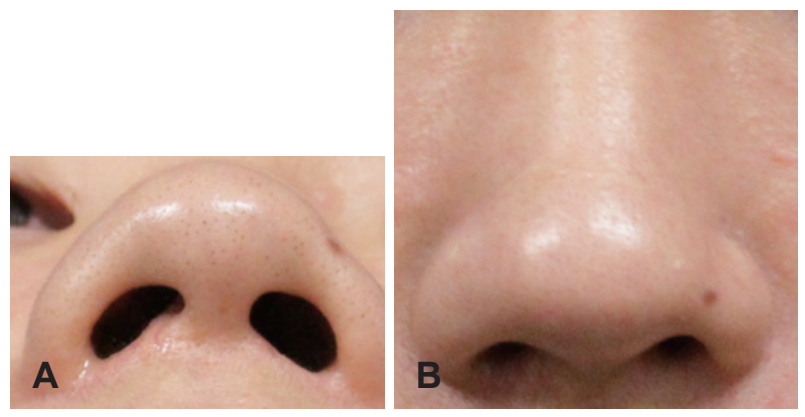

Fig. 6. Eight-month postoperative basal $(A)$ and frontal view (B) show no deformity, scar and recurrence sign.

\section{고 찰}

다형성 선종은 타액선이 존재하는 모든 구역에서 발병이 가능하나 비강 내 다형성 선종은 매우 희귀한 질환이다. 비 강 내 다형성 선종이 발생하는 원인에 대해서는 아직 이견이 많으나 비중격에, 여자에서, 30 50대 사이에 더 발병률이 높 게 보고되고 있다.1) 본 증례는 더 드물게도 27세의 젊은 남자 에서 비익 피부에 생긴 다형성 선종이었다. 비익에 발생한 다 형성 선종은 현재까지 국내에서는 보고된 바가 없고 해외에 서 2예 보고가 되었다. 2예에서 모두 비강 내로 접근하여 병 변을 제거하고 단순 봉합하였으며 6개월 이상 추적 관찰 시 재발의 소견은 없었다고 보고하고 있다.7.8

피부에 생긴 다형성 선종은 피부기름샘(sebaceous glands), 땀샘(sweat glands), 이소성 타액선(ectopic salivary glands) 등에서 기원한 것으로 생각하고 있다. ${ }^{8,9}$ 타액선조직에서 기원 하였다는 이론에서는 발생 과정상 이상 혹은 정상 상피조직 의 변화 등의 가설들이 제시되고 있지만 아직 정확한 원인은 모른다. ${ }^{10,11}$
코에 다형성 선종이 생겼을 때 대부분 증상이 없고 종양이 느리게 성장하기 때문에 초기에 발견하기 힘들다. 환자들은 코막힘, 코피, 종괴의 발견 등을 주소로 내원하게 되며 비경 검사나 비내시경 검사상에서 주로 처음 발견된다. ${ }^{12)}$ 코에 종양 이 관찰되었을 때 감별해야 할 질환들로 편평세포암종(squamous cell carcinoma), 악성흑색종(malignant melanoma) 등 악성종양과 다형성 선종(pleomorphic adenoma), 혈관섬 유종(angiofibroma), 혈관종(hemangioma) 등 양성종양이 있으며, 모두 흔하지 않은 종양으로 악성이 의심되거나 양성 으로 보여도 코막힘, 비출혈 등의 증상이 있을 때 적극적으로 진단하고 치료를 시행해야 한다. ${ }^{13)}$ 특히, 다형성 선종은 다형 성 선종 유래 암종(carcinoma ex pleomorphic adenoa) 등으 로 악성화 가능성이 있으므로 발견 시 치료가 필수적으로 행 해져야 한다. ${ }^{14)}$

다형성 선종은 캡슐로 싸여 있고 주변 조직과 경계가 명확 하며, 조직학적으로 상피세포들의 증식이 관찰되고 이것이 점액성 기질과 이원성으로 존재한다. 이하선이나 악하선에서 기원하는 다형성 선종은 기질이 풍부한데 반해 비강 내 다형 성 선종은 세포성분의 밀도가 높다. 수술적 치료 후 다형성 선종의 재발은 대부분의 경우 수술 부위에 퍼진 기질 때문이 라고 설명되며, 이는 비강 내 다형성 선종의 재발이 드문 것의 이론적 근거가 된다. ${ }^{15)}$ 이번 증례 역시 세포 성분의 밀도가 높 은 것을 확인할 수 있다.

치료는 정상 조직을 포함하여 적절한 변연을 확보한 외과 적 절제가 원칙이며 수술적 접근은 종양의 크기, 위치 등에 따라 비내접근법, 측비절개술, 안면부노출술 등으로 달라질 수 있다. ${ }^{1,6)}$ 수술 중 종양의 피막이 찢어지거나 불완전하게 제 거되면 국소적으로 재발할 수 있으므로 종양의 완전한 절제 가 최우선적으로 고려되어야 하고, 수술 후 회복, 미용적 면을 고려하여 보다 덜 침습적인 수술 방법 선택이 가능하며 결손 부위가 크면 적절한 재건술을 시행한다. 본 예에서도 다형성 선종이 하외측연골 외측각을 침범하고 있어 그 일부를 같이 절제하였고, 결손이 생긴 부위는 비중격 연골의 일부를 채취 해 재건해주었다. 이처럼 결손 부위가 크지 않은 경우, 비중격 연골을 이용한 재건은 동일한 수술 시야에서 쉽게 채취가 가 능하고 연골 채취에 따른 추가적인 흥터 등 합병증의 위험성 이 낮다는 장점이 있다.

본 증례는 비익에 발생한 다형성 선종이 하외측연골을 침 범한 드문 증례로 하외측연골의 일부를 제거하고 비중격 연 골로 재건을 하였다는 점에서 기존의 보고들과 차이점을 보 인다. 코에 발생한 다형성 선종은 아주 드문 질환으로 치료로 수술 시 완전한 절제가 우선되어야 하지만 미용적인 면과 술 후 부작용을 고려하고 수술 후 결손 부위를 적절히 재건하 
는 것이 고려되어야 하며 충분한 기간 동안에 추적 관찰이 필요하리라 생각된다.

\section{Acknowledgments}

None.

\section{Author Contribution}

Conceptualization: Soo Young Choi. Methodology: Soo Young Choi, Hee Jin Kang. Project administration: Jin-Young Min. Supervision: Sung Wan Kim, Jin-Young Min. Validation: Jin-Young Min. Visualization: Hee Jin Kang. Writing — original draft: Soo Young Choi. Writing — review \& editing: Sung Wan Kim, Jin-Young Min.

\section{ORCIDs}

Jin-Young Min https://orcid.org/0000-0003-1890-2451

Soo Young Cho https://orcid.org/0000-0003-2056-4797

Sung Wan Kim https://orcid.org/0000-0002-6100-8634

\section{REFERENCES}

1) Sciandra D, Dispenza F, Porcasi R, Kulamarva G, Saraniti C. Pleomorphic adenoma of the lateral nasal wall: Case report. Acta Otorhinolaryngol Ital 2008;28(3):150-3.

2) Gluckman JL, Barrord J. Nonsquamous cell tumors of the minor salivary glands. Otolaryngol Clin North Am 1986;19(3):497-505.

3) Wenig BL, Sciubba JJ, Cohen A, Abramson AL. Pleomorphic adenoma of the nasal septum. Otolaryngol Head Neck Surg 1985; 93(3):432-6.

4) Ceylan A, Celenk F, Poyraz A, Uslu S. Pleomorphic adenoma of the nasal columella. Pathol Res Pract 2008;204(4):273-6.
5) Badia L, Weir JN, Robinson AC. Heterotopic pleomorphic adenoma of the external nose. J Laryngol Otol 1996;110(4):376-8.

6) Park SK, Heo KW, Choi ES, Kang MS. A case of pleomorphic adenoma of the nasal vestibule. Korean J Otolaryngol 2003;46(3): $250-2$.

7) Sung KY, Kim YH, Lee SK, Lee SY. An unusual presentation of pleomorphic adenoma: Nasal ala. J Craniofac Surg 2012;23(6): e641-2.

8) Mouzali A, Lameche S, Slimani A, Zemirli O. Pleomorphic adenoma of the ala nasi: A case report. Clin Med Insights Ear Nose Throat 2019;12:1179550619886561.

9) Nishimura S, Murofushi T, Sugasawa M. Pleomorphic adenoma of the auricle. Eur Arch Otorhinolaryngol 1999;256(1):22-4.

10) Ersner MS, Saltzman M. A mixed tumour of the nasal septum. Report of a case. Laryngoscope 1944;54(6):287-96.

11) Boffi A, Fridman L. Salivary heterotopic tissue in lower neck. J Laryngol Otol 1973;87(9):905-7.

12) Compagno J, Wong RT. Intranasal mixed tumors (pleomorphic adenomas): A clinicopathologic study of 40 cases. Am J Clin Pathol 1977;68(2):213-8.

13) Harbo G, Grau C, Bundgaard T, Overgaard M, Elbrønd O, Søgaard $\mathrm{H}$, et al. Cancer of the nasal cavity and paranasal sinuses. A clinico-pathological study of 277 patients. Acta Oncol 1997;36(1): 45-50.

14) Li W, Lu H, Zhang H, Lai Y, Zhang J, Ni Y, et al. Sinonasal/ nasopharyngeal pleomorphic adenoma and carcinoma ex pleomorphic adenoma: A report of 17 surgical cases combined with a literature review. Cancer Manag Res 2019;11:5545-55.

15) Nonomura N, Niijima H, Kimura O, Ikarashi F, Nakano Y, Kimura $\mathrm{K}$. Immunohistochemical study of pleomorphic adenoma of the nasal septum. Auris Nasus Larynx 1992;19(2):125-31. 